\title{
OBSERVATIONS ON THE LIFE HISTORY OF GIANT WATER BUGS LETHOCERUS MAYR, 1853 (HETEROPTERA: NEPOMORPHA: BElOSTOMATIDAE) IN THE GANGETIC PLAINS OF INDIA AND NEPAL
}

\section{Hasko Nesemann ${ }^{1}$ \& Gopal Sharma ${ }^{2}$}

OPEN ACCESS

${ }^{1}$ Ashokraj Path, Sonapalace, Mahendru, Patna, Bihar 800006, India

${ }^{2}$ Zoological Survey of India, Gangetic Plains Regional Centre, Rajendra Nagar, Patna, Bihar 800016, India

${ }^{1}$ hnesemann2000@yahoo.co.in (corresponding author), ${ }^{2}$ gprszsipatna@rediffmail.com

\begin{abstract}
Two species of giant water bugs Lethocerus were found in the Gangetic plains of northern India and Nepal. Lethocerus indicus is widespread, whereas a single record of Lethocerus patruelis confirms the eastern distribution range in Bihar. Four instars of aquatic nymphs occur exclusively in temporary shallow stagnant water bodies which harbor rich amphibian populations but lack permanent fish fauna. From mid-August to the first week of November adults fly. Later they live submerged in aquatic habitats of large rivers and permanent stagnant water bodies which harbor diverse fish fauna. Repeated findings of adults with ventrally attached egg-shaped pupae of aquatic mites (Hydracarina) suggest that these are host-specific ones of Lethocerus. Thus, the occurrence of protelean parasites on giant water bugs in the Gangetic plains is a previously unknown unique finding since apparently mites have been noticed only from other Nepomorpha families.
\end{abstract}

Keywords: Aquatic insect, gangetic plains, giant water bug, hydracarina, host-specificity, India, life cycle, Nepal, protelean mites.

Hindi Abstract: विशाल वाटर बग ल्रिशोसेरस की दो प्रजातियाँ उत्तर भारत के गंगोटिक प्लेन एवं केपाल में मिलता था जबकि लिथोसेरस इण्डिकस भारत एवं केपाल में दूर-दूर तक फैला हुआ था, क्योंकि लिथोसेरस पैद्रूएलिस का बिहार के पूर्वी क्षेत्रों में एकमात्र सिंगल रिकोई का मिलना इसे सुनिश्चित करता है. इस प्रजाति के जलीय निम्फ का चार ईन्सटार जो कि विशेष रूप से अस्थायी छिछ्छा स्थिर पानी जो कि उभयचर (एम्फिबियन) के जनसमूह को अच्छी तरह से आभ्रय देता है, में मिलता है. किन्तु इस छिछला स्थिर पानी में स्थायी रूप से मछ्छी नहीं मिलता है. अगस्त के मध्य से एवं नबक्वर के प्रथम सप्ताह तक इनके व्यस्क उङने लगते हैं, बाद में वे बडे नदियों तथा स्थिर स्थायी जलीय वातावरण के सबमर्ज्ड अधिवास में रहते हैं, जहां विभिन्न तरह की मछल्रियाँ आश्रय लेती हैं. व्यस्क ल्रिथोसेरस के निचत्रे हिस्से में जलीय माईटस का अंडाकार प्यूपा का बार-बार मिलना यह बताता है कि जलीय माईटस (हाईड्रकैरीना) ल्लिथोसेरस का होस्ट स्पेसिफिक हैं. इस प्रकार गंगेटिक प्लेन में प्रोटीलियन पारासाईटस का विशाल वाटर बग के शरीर के अपृष्ठीय (भेनटरल) भाग पर पाया जाना एक अनूठा अविष्कार है, जिसकी जानकारी पहले से नहीं थी. इस माईट्स का पूर्णरूप से मात्र दूसरे नोपोमोर्फा परिवार के शरीर पर मिलने कि सूचना है.

DOI: http://dx.doi.org/10.11609/JoTT.o3497.4474-82 | ZooBank: urn:Isid:zoobank.org:pub:4E39AE2A-1F27-4B89-8477-081020FEA48A

Manuscript details: Ms \# 03497 | Received 29 January 2013 | Final received 31 March 2013 | Finally accepted 03 June 2013

Citation: Hasko Nesemann \& Gopal Sharma (2013). Observations on the life history of giant water bugs Lethocerus Mayr, 1853 (Heteroptera: Nepomorpha: Belostomatidae) in the Gangetic plains of India and Nepal. Journal of Threatened Taxa 5(10): 4474-4482; http://dx.doi.org/10.11609/JoTT.03497.4474-82

Copyright: @ Nesemann \& Sharma 2013. Creative Commons Attribution 3.0 Unported License. JoTT allows unrestricted use of this article in any medium, reproduction and distribution by providing adequate credit to the authors and the source of publication.

Funding: First author: Scholar-In-Residence under the UGC scheme at Central University of Bihar funded through the University Grants Commission, New Delhi.

Second author: Annual research program for aquatic faunal study of rivers of Jharkhand under Ministry of Environment and Forests.
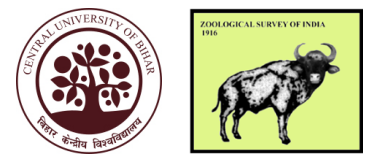

Competing Interest: None.

Acknowledgements: We thank the University Grants Commission (New Delhi, India), Central University of Bihar (Patna, India) , Dr. K. Venkataraman, Director, Zoological Survey of India, Kolkata, R.K. Sinha (Department of Zoology, P.U., Patna, India), Ram Kumar (Centre for Environmental Science, CUB, Patna, India), Deep Narayan Shah and Ram Devi Tachamo Shah (Department of Limnology and Nature Conservation, Senckenberg Research Institutes and Natural History Museums, Gelnhausen, Germany) for their kind help in fieldwork; Herbert Zettel (Entomological Department, Natural History Museum Vienna, Austria) for valuable support, encouragements and discussion.

Author Contribution: HN and GS conducted fieldworks and equally contributed in manuscript preparation. HN illustrated the specimens.

Author Details: HASKO NESEMANN is expert in aquatic biology and GOPAL SHARMA is aquatic biologist and freshwater dolphin expert. They are specialized in aquatic biodiversity with a keen interest in freshwater ecology, biogeography, conservation, and ecological water quality monitoring. 


\section{INTRODUCTION}

Aquatic bugs of the infraorder Nepomorpha are hemimetabolous insects. The juvenile stages (nymphs) are similar to the adult forms but they are distinguished by the successive growth of their wing pads. The nymphs are fully aquatic whereas many of the winged mature Nepomorpha can fly. This is an important strategy in the life cycle for active dispersal and colonization of new habitats. The largest arthropods in freshwaters are mostly represented by decapods Crustaceans like crabs, prawns and crayfish but several aquatic bugs are noticeably robust insects of an unusually large size with raptorial forelegs. Belostomatidae are named giant water bugs with about 160 accepted species worldwide of three subfamilies (Polhemus \& Polhemus 2008; Morse 2009; Henry 2009). Some members of the subfamily Lethocerinae reach 109-115 mm total body length, the maximum size of adult aquatic insects (Perez-Goodwyn 2006). Their distribution range includes the circumtropical, subtropical and warm-temperate zones of all continents. The family Belostomatidae also shares several characters with the definition of "living fossils" since similar representations of these bugs are already known as fossil documentations from the Upper Triassic of Virginia (North America) since 210 Million years ago (Andersen \& Weir 2004). The oldest Lethocerinae are found in the Jurassic of Germany with Mesobelostomum depertitum (Germar, 1839) (Ponomarenko 1985; Popov 1992). At present three extant genera Benacus Stål, 1861 (monotypic), Kirkaldyia Montandon, 1909 (monotypic), and Lethocerus Mayr, 1853 (22 species) are recognized with 24 species. The highest diversity with 17 species is observed in the neotropical region (PerezGoodwyn 2006; Choate 2011). Records of tropical Asian Lethocerinae species are scattered in the literature (Easton \& Wing-Wah Pun 1997; Sharma 1998; Bal \& Basu 2002; Nahar 2004; Chen et al. 2005; Lekprayoon et al. 2007; Nesemann et al. 2012), only Thirumalai (2007) has summarized the distribution for India. Giant water bugs of the genus Lethocerus are traditionally used as human food in South-East Asia.

Lethocerinae appear to be a well-studied group of large-sized insects which is reflected in a comparatively high number of articles and book chapters dealing with their biology (Dudgeon 1999; Deckert \& GöllnerScheiding 2003; Polhemus \& Polhemus 2008; Morse 2009; Henry 2009). Perez-Goodwyn (2006: 7) stated: "The reproductive behavior is peculiar in the family and different to that of Belostomatinae. The female lays her eggs outside the water ("emergent brooders" according to Smith 1997) on a vegetal substratum (sticks, so far as known, but L. mazzai chooses moss at the border of the ponds as substratum, see De Carlo, J.M. 1962). The male guards the eggs until hatching, keeping them moist and defending them from predators." Biological observations of four American and two Oriental species are published, namely Lethocerus americanus (Leidy, 1847) (Hoffman 1924; Hungerford 1925), Lethocerus maximus De Carlo, 1938 (Cullen 1969), Lethocerus mazzai De Carlo, 1961 (De Carlo 1969), Lethocerus medius (Guérin-Méneville, 1857) (Smith \& Larsen 1993) and Lethocerus indicus (Lepeletier \& Serville 1825) (Hoffman 1933a,b). The behavior of Kirkaldyia deyrolli (Vuillefroy 1864) is the best known, and is one of the reference points for the post-embryonic paternal care in insects (Ohba 2011). The life-cycle of these five species was supposed to be, in general, valid for other Lethocerinae including the old world members (Dudgeon 1999). Eggs of Lethocerus delpontei De Carlo, 1930 and Kirkaldyia deyrolli were described by Perez-Goodwyn et al. (2006: 155) and the authors assumed: "Due to the increase in size of the adults in order to have access to a vertebrate diet, the eggs should also increase in size." Aquatic mites (Arachnida: Acari: Hydracarina) were only accidentally noticed in association with Lethocerus spp. (Marlos 2010a) but regularly reported from other Nepomorpha (Proctor 1998; Hawking et al. 2009; Marlos 2010b).

\section{MATERIAL AND METHODS}

During field studies of benthic macro-invertebrate fauna the aquatic bugs were collected with the help of a $1 \mathrm{~mm}$ mesh sized net by hand from the shallow zones of running and stagnant waters. Rivers and wetlands of the Gangetic plains were studied in Bihar, Jharkhand, West Bengal, New Delhi and Nepal and a total of 17 localities for Lethocerus species were discovered from 2004-2012 (Fig. 1). A few flying adults were also collected near light sources. All other records are nymphs and adults from aquatic habitats. The material was preserved together with all available benthic macro-invertebrates in a mixture of ethanol and formaldehyde for hardening the insects. After washing and sorting the specimens were kept in separate jars, labeled and transferred into $70 \%$ ethanol. The maximum body length and the width of all specimens was measured using a slide caliper. In adult specimens the distinction of males and females was based on the genital plate which was studied with a Leica stereo-zoom microscope. Attached pupae were studied by a high magnification Olympus microscope. 


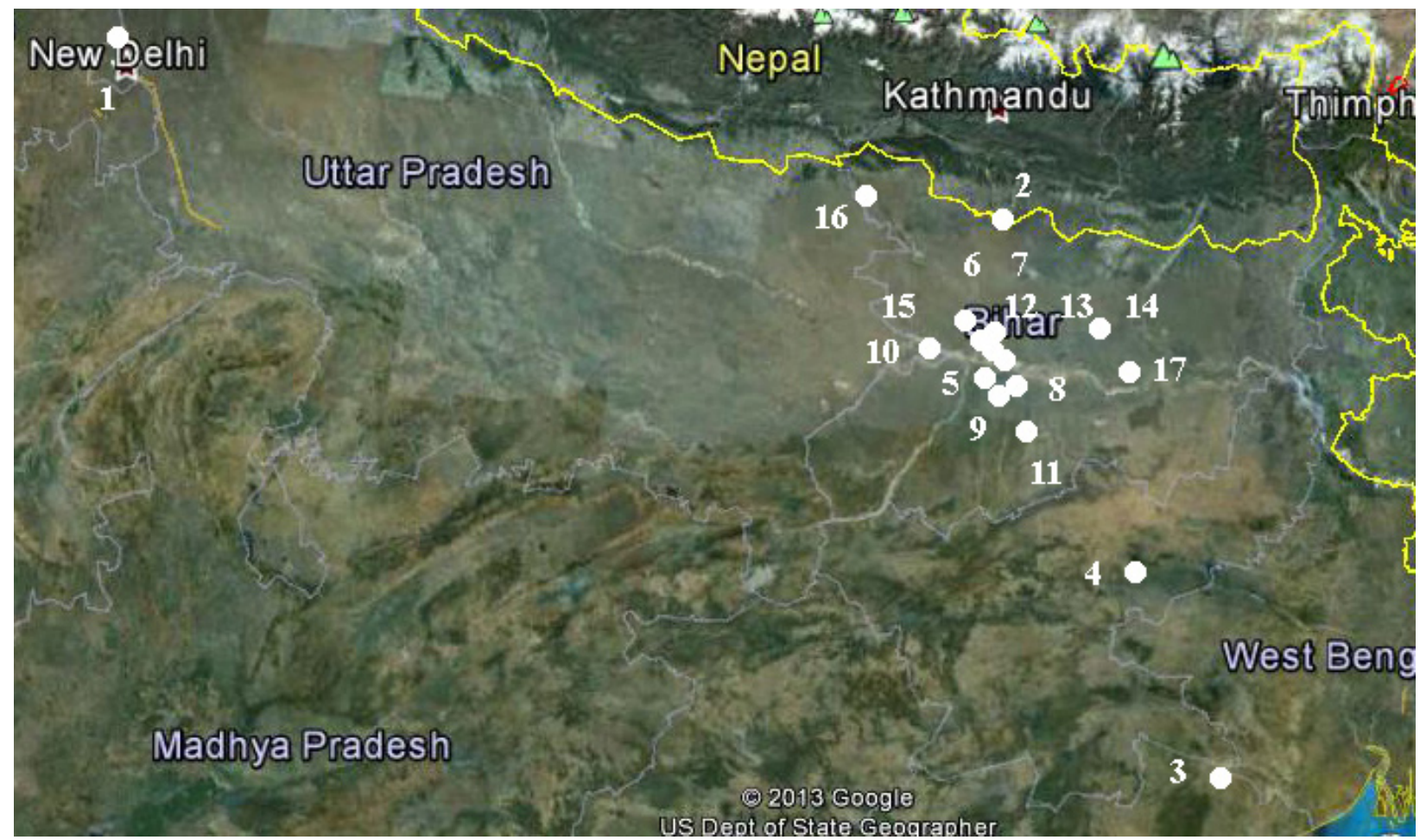

Figure 1. Map of sampling sites in the Gangetic plains of India and Nepal .

Identification of adults was done with the keys provided by Menke (1960) and Perez-Goodwyn (2006). The voucher material is deposited in the collection of the Zoological Survey of India, Gangetic Plains Regional Centre in Patna. All specimens deposited with their location and registration numbers are listed in the results.

\section{RESULTS}

Two species of giant water bugs could be identified. Lethocerus spp. was found in eight lowland rivers and eight stagnant water bodies of the floodplains. The aquatic habitats of adults were predominantly large rivers but also one oxbow lake and one pond, whereas the exclusively aquatic nymphs (or larvae) were found only in temporary shallow ditches of riverine floodplains. These reproduction habitats are all characterized by seasonal water during the monsoon period starting from the month of June/July onwards. They dry completely after the following winter and are not inhabited by any fish fauna. The aquatic vertebrate fauna herein consist of tadpoles and adult amphibians which were abundantly found during the inundation period.

\section{Lethocerus indicus (Lepeletier \& Serville, 1825)}

New Delhi:

1. River Yamuna at Jangshola near Palla: $28^{\circ} 51^{\prime} 24^{\prime \prime} \mathrm{N} \& 77^{0} 12^{\prime} 27^{\prime \prime} \mathrm{E}$, elevation 210m, 01.iv.2004, 1 adult collected in dense Hydrilla verticillata plants, released, coll. Rajiv Kumar \& H. Nesemann.

Nepal:

2. Rautahat District: Barahwa Nadi (Ox-bow Lake) East of Gaur, $26^{\circ} 46^{\prime} 13^{\prime \prime} \mathrm{N} \& 85^{\circ} 16^{\prime} 53^{\prime \prime} \mathrm{E}$, elevation $77 \mathrm{~m}$, 06.v.2006, 1 adult male with ventrally attached pupae, collected in dense Ceratophyllum demersum plants, coll. H. Nesemann \& ASSESS-HKH party (ZSI/GPRC/IV-3035). West Bengal:

3. RiverSubernarekha at Gopiballabhpur upstream road bridge: $22^{\circ} 13^{\prime} 15^{\prime \prime} \mathrm{N} \& 86^{\circ} 54^{\prime} 01^{\prime \prime} \mathrm{E}, 20 . x \mathrm{i} 2008,1$ adult the specimen was collected from the small pool below the river bridge pillar, elevation $36 \mathrm{~m}$, coll. G. Sharma \& GPRC party (ZSI/GPRC/IV-3023). Jharkhand:

4. River Damodar at Fushro bridge, Chandrapura: $23^{\circ} 45^{\prime} 40^{\prime \prime} \mathrm{N} \& 86^{\circ} 00^{\prime} 50^{\prime \prime} \mathrm{E}$, elevation 205m, 28.ix.2010, 1 adult female with few ventrally and dorsally attached pupae, collected from the slow water current attached with aquatic macrophytes, coll. G. Sharma \& GPRC party (ZSI/GPRC/IV-3021). 
Bihar:

5. Patna: BIT Campus near Airport: flying adults, collected in evening near light of sports ground $25^{\circ} 55^{\prime} 45^{\prime \prime} \mathrm{N} \& 85^{\circ} 05^{\prime} 16^{\prime \prime}$, elevation 55.4m,08-10.x.2010, 1 female, 3 males, inside BIT Canteen "Mother's Food", 15.viii.2011, 1 female, coll. H. Nesemann (ZSI/GPRC/IV3022).

6. River Ganga at Patna, upstream Darbhanga House: $25^{\circ} 37^{\prime} 19^{\prime \prime} \mathrm{N} \& 8^{\circ} 09^{\prime} 46^{\prime \prime} \mathrm{E}$, elevation 50.6m, 28.ii.2012, 1 adult male collected under large stones in shallow water, coll. H. Nesemann (ZSI/GPRC/IV-3034).

7. River Gandak at Ramnagar upstream Hajipur: $25^{\circ} 48^{\prime} 07^{\prime \prime} \mathrm{N} \& 85^{\circ} 10^{\prime} 33^{\prime \prime} E$, elevation 53m, 23.v.2012, 1 adult female collected from unvegetated open water of the river bank at the water's edge, coll. G. Sharma \& H. Nesemann (ZSI/GPRC/IV-3024).

8. River Punpun upstream Fatehpur (south of Patna): $25^{\circ} 30^{\prime} 12^{\prime \prime} \mathrm{N}$ \& $85^{\circ} 11^{\prime} 37^{\prime \prime} \mathrm{E}$, elevation 52m, 12.v.2012, 1 adult male collected from unvegetated open water of the river bank at the water's edge, coll. $\mathrm{H}$. Nesemann (ZSI/GPRC/IV-3025).

9. River Punpun at Masauri-Railway bridge upstream road bridge (south of Patna): $25^{0} 30^{\prime} 06^{\prime \prime} \mathrm{N} \&$ $85^{\circ} 06^{\prime} 06^{\prime \prime}$, elevation 54m, 19.v.2012, 1 adult male with ventrally attached pupae, collected under large stones near Vallisneria spirallis plants in the middle of the river bed, coll. G. Sharma \& H. Nesemann (ZSI/GPRC/IV3026).

10. River Ghaghara at Manjhi bridge: $25^{\circ} 49^{\prime} 19^{\prime \prime} \mathrm{N}$

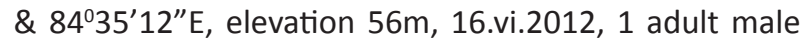
with ventrally attached pupae, collected in dense Potamogeton pectinatus plants from an isolated pool ( $>1.5 \mathrm{~m}$ water depth) next to the main channel's left bank, coll. G. Sharma \& H. Nesemann (ZSI/GPRC/IV-3027).

11. Nalanda District: Small fish-pond in village

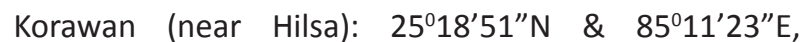
elevation 59.3m, 02.xi.2011, 1 adult female collected from the bottom, coll. G. Sharma \& H. Nesemann (ZSI/ GPRC/IV-3028).

12. Hajipur, Small pond with Pila globosa west

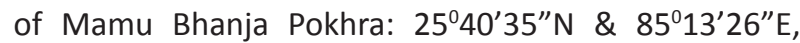
elevation 52.4m, 16.vii.2011, 1 nymph collected from shallow water in submerged grasses, coll. H. Nesemann. Additional nymphs were observed (ZSI/GPRC/IV-3029).

13. Hajipur, Shallow ditch north-west of Mamu Bhanja Pokhra: $25^{\circ} 40^{\prime} 30^{\prime \prime} \mathrm{N} \& 85^{\circ} 13^{\prime} 32^{\prime \prime} \mathrm{E}$, elevation 52.4m, 16.vii.2011, 1 nymph, coll. H. Nesemann. 24.vii.2011, 3 nymphs, 03.viii.2011, coll. G. Sharma \& H. Nesemann, 1 nymph, 26 ${ }^{\text {th }}$ August 2012, 1 nymph, collected from shallow water in submerged grasses, coll. $\mathrm{H}$. Nesemann. Additional nymphs were observed (ZSI/
GPRC/IV-3030, ZSI/GPRC/IV-3036).

14. Gandak floodplain, embankment upstream Hajipur, Ramnagar Kund, medium-sized (temporary monsoon) pond in Mangifera indica orchards: $25^{\circ} 48^{\prime} 11^{\prime \prime} \mathrm{N}$ \& $85^{\circ} 10^{\prime} 46^{\prime \prime} \mathrm{E}$, elevation 57.3m, 14.viii.2011, 2 nymphs, 29.vii.2012, 5 nymphs, collected from shallow water in submerged grasses, coll. G. Sharma \& H. Nesemann. Additional nymphs were observed (ZSI/GPRC/IV-3032).

15. Gandak floodplain, embankment near Vaishali, shallow floodplain ditch (open meadow) near of Bherampur: $25^{\circ} 55^{\prime} 03^{\prime \prime} \mathrm{N} \& 85^{\circ} 06^{\prime} 58^{\prime \prime} \mathrm{E}$, elevation $57.9 \mathrm{~m}$, 07.viii.2011, 2 nymphs collected from shallow water in submerged grasses, coll. G. Sharma \& H. Nesemann (ZSI/ GPRC/IV-3033).

16. Valmiki Tiger Reserve and Sanctuary: Gandak floodplain: Temporary shallow ditch near Rohua Nala, Madanpur Forest Range, surrounding dense mixed bushy forest and reed: $27^{\circ} 11^{\prime} 38^{\prime \prime} \mathrm{N} \& 83^{\circ} 59^{\prime} 41.84^{\prime \prime} E$, elevation $97 \mathrm{~m}, 09 . v i i .2012,1$ nymph collected from shallow water in submerged grasses, coll. G. Sharma \& H. Nesemann (ZSI/GPRC/IV-3037).

\section{Lethocerus patruelis (Stål, 1854)}

17. River Budhi Gandak at Seuri-Bridge North of Begusarai: $25^{\circ} 32^{\prime} 24^{\prime \prime} \mathrm{N} \& 86^{\circ} 07^{\prime} 50^{\prime \prime} \mathrm{E}$, elevation $42 \mathrm{~m}$, 26.v.2012, 1 adult male with 45 ventrally attached pupae, collected in dense Vallisneria spiralis plants, coll. H. Nesemann \& Ram Kumar (ZSI/GPRC/IV-3038).

\section{Biological observations}

A total of 35 specimens of Lethocerus indicus were included in the present analysis (Image 1), these are in particular 22 nymphs, eight male and five female adults (Table 1). The nymphs can be grouped into four different instars according to their body size; the length is given here in $\mathrm{mm}$. The first available development stage ( $1^{\text {st }}$ instar on Image 1 ) ranges from $8.5-9.3 \mathrm{~mm}$ and is represented by six individuals but approximately one dozen of the same sized nymphs were additionally observed in localities no. 12 and 13 at Hajipur. The next following instars reaching $13-19.5 \mathrm{~mm}\left(2^{\text {nd }}\right.$ instar on Image 1, two nymphs), $30-33.1 \mathrm{~mm}$ ( $3^{\text {rd }}$ instar on Image 1 , seven nymphs) and $47-52 \mathrm{~mm}$ ( $4^{\text {th }}$ instar in Image 2 , seven nymphs) respectively. The presence of aquatic nymphs was observed only in the months of July and August.

The adults were identified males or females based on the different shape of the genital plates (Images $3,4)$. The male individuals reach $64-73 \mathrm{~mm}$ whereas the females are generally larger with $73-76.3 \mathrm{~mm}$ body length. Submerged diving adults were observed in large 


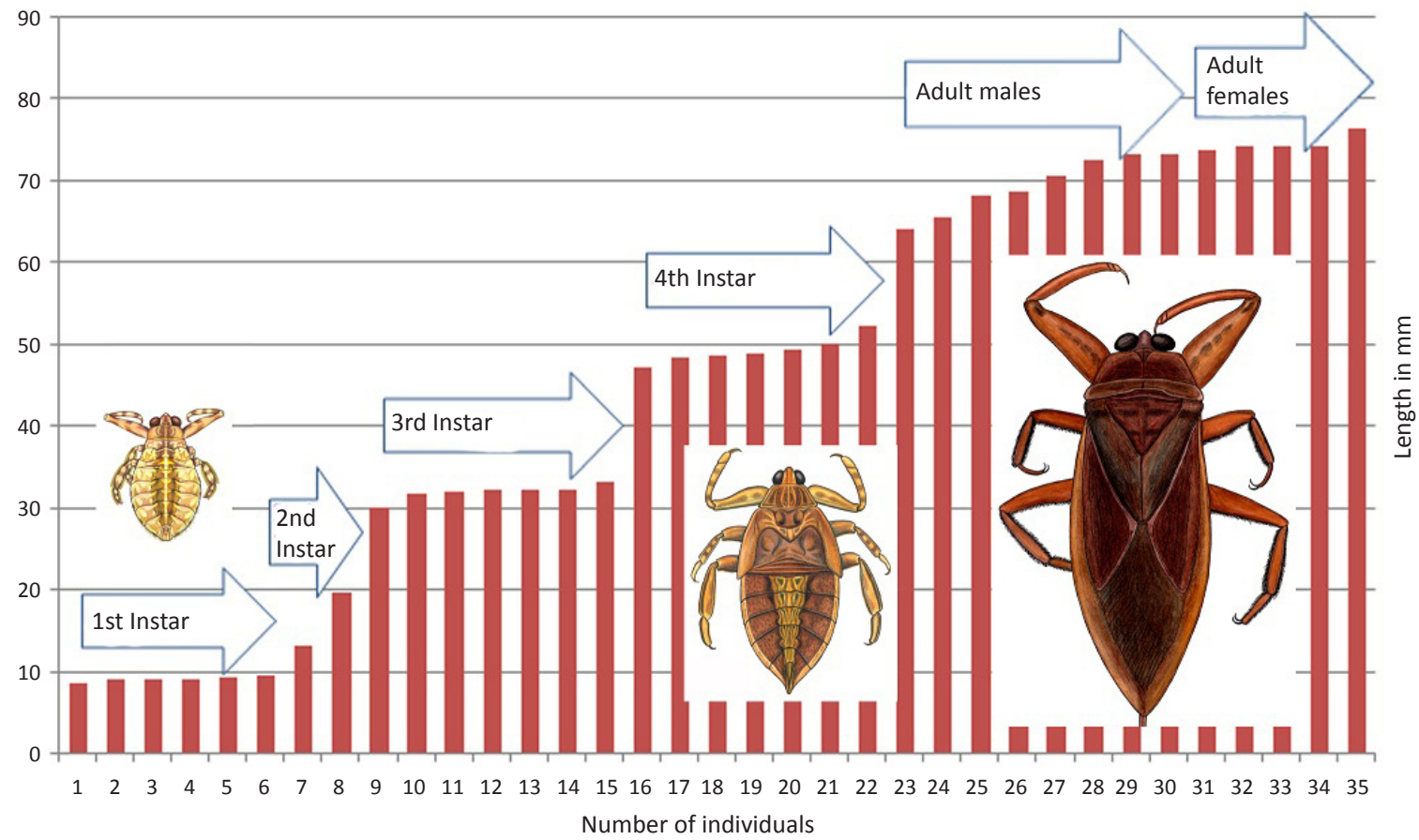

Image 1. Length frequency of the Lethocerus indicus population from the Gangetic plains. Four instar stages of nymphs plus adults were recorded in nature.

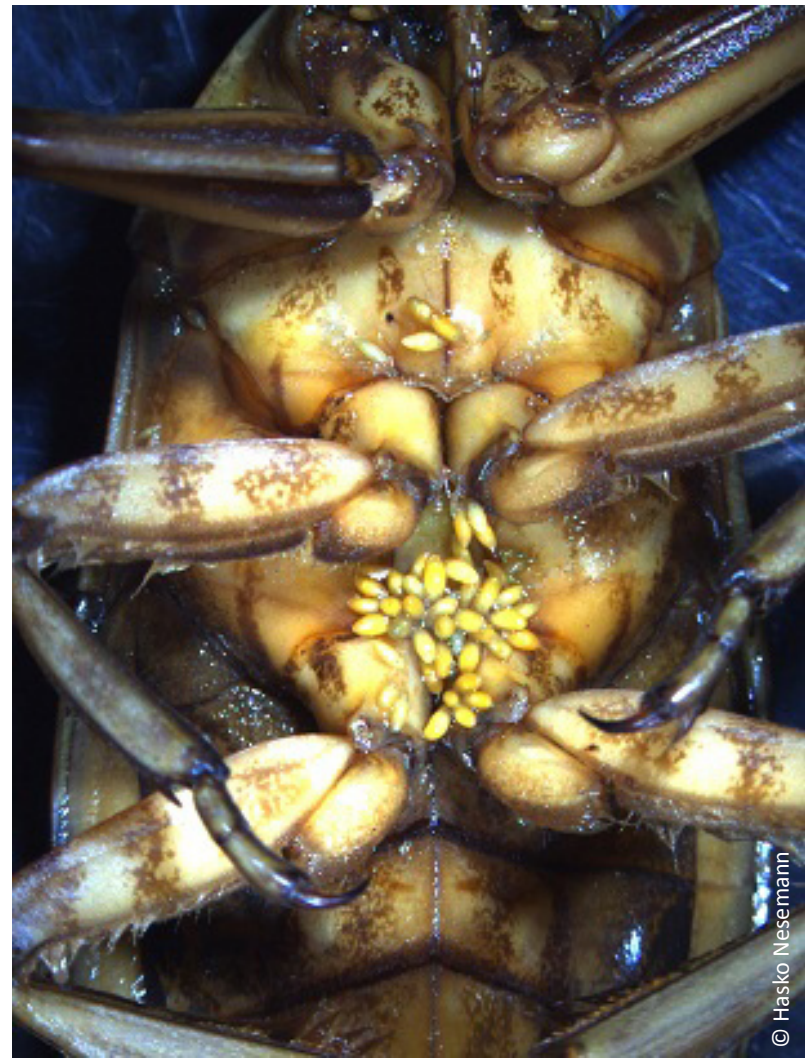

Image 2. Lethocerus patruelis, ventral side of adult male from locality no. 17 with attached pupae of juvenile mites (Hydracarina). and deep water bodies in the months of February, May, June, September and November. A single flying terrestrial adult was found in the month of August whereas they could be frequently seen in large numbers during the month of October, the monsoon not ending until the first week of November.

Three adult males and one female individual of the preserved material bear upto 7-47 ventrally attached pupae on the underside of the thorax and between the second and third pairs of legs. These are 'protelean parasites' with inactive pupa-like stages (Proctor 1998; Hawking et al. 2009) that represent the 'protonymph' and 'tritonymph' of aquatic mites (Acari: Cohort Parasitengona: Hydracarina) having striking similarity with eggs of Nepomorpha (Andersen \& Weir 2004). The pupae of $1.0 \mathrm{~mm}$ total length (Images 5,6 ) contain aquatic mites with four visible eye spots and readily developed legs. They have a yellowish-ochre color with white apices. The pupae-bearing male giant water bugs were found in the months May and June. A single female individual with only a few attached pupae from Damodar River was collected during floods in the month of September. Repeated observations of adults with ventrally attached pupae suggest that these are host-specific mites of Lethocerus spp. and they are not deposited accidentally using giant water bugs as substrate.

The single adult male specimen measured $55.2 \mathrm{~mm}$ 
Table 1. Sampling data and measurements of Lethocerus indicus preserved material.

\begin{tabular}{|c|c|c|c|c|c|c|c|}
\hline $\begin{array}{l}\text { Locality } \\
\text { number }\end{array}$ & Sampling date & Sampling year & Length (mm) & Width (mm) & Ontogeny & Gender (Adults) & Hydracarina \\
\hline 14 & 26.08. & 2012 & 8.5 & 3 & nymph & & \\
\hline 14 & 16.07. & 2011 & 9 & 3.5 & nymph & & \\
\hline 14 & 19.07. & 2011 & 9 & 3.7 & nymph & & \\
\hline 14 & 19.07. & 2011 & 9 & 3.7 & nymph & & \\
\hline 14 & 19.07. & 2011 & 9.2 & 4 & nymph & & \\
\hline 14 & 16.07. & 2011 & 9.3 & 4 & nymph & & \\
\hline 13 & 16.07. & 2011 & 13 & 6.5 & nymph & & \\
\hline 17 & 09.07. & 2012 & 19.5 & 8.3 & nymph & & \\
\hline 14 & 29.07. & 2012 & 30 & 13.5 & nymph & & \\
\hline 15 & 29.07. & 2012 & 31.5 & 13.5 & nymph & & \\
\hline 15 & 29.07. & 2012 & 31.8 & 12.7 & nymph & & \\
\hline 15 & 29.07. & 2012 & 32 & 14 & nymph & & \\
\hline 15 & 29.07 & 2012 & 32 & 15 & nymph & & \\
\hline 15 & 29.07. & 2012 & 32 & 14 & nymph & & \\
\hline 14 & 24.07 & 2011 & 33.12 & 13.1 & nymph & & \\
\hline 16 & 14.08. & 2011 & 47 & 21.7 & nymph & & \\
\hline 15 & 14.08. & 2011 & 48.3 & 21 & nymph & & \\
\hline 14 & 03.08. & 2011 & 48.4 & 22.3 & nymph & & \\
\hline 14 & 24.07 & 2011 & 48.78 & 20.34 & nymph & & \\
\hline 14 & 24.07. & 2011 & 49.13 & 23.16 & nymph & & \\
\hline 15 & 14.08. & 2011 & 50 & 23.5 & nymph & & \\
\hline 16 & 14.08 & 2011 & 52 & 22.5 & nymph & & \\
\hline 10 & 19.05 & 2012 & 64 & 24 & adult & male & attached ventrally \\
\hline 9 & 12.05. & 2012 & 65.5 & 24 & adult & male & \\
\hline 11 & 16.06 & 2012 & 68 & 25 & adult & male & attached ventrally \\
\hline 6 & 10.10. & 2010 & 68.5 & 26 & adult & male & \\
\hline 7 & 28.02. & 2012 & 70.5 & 26.1 & adult & male & \\
\hline 6 & 10.10. & 2010 & 72.3 & 26.2 & adult & male & \\
\hline 8 & 23.05 & 2012 & 73 & 26.5 & adult & female & \\
\hline 6 & 10.10 & 2010 & 73 & 26.3 & adult & male & \\
\hline 12 & 02.11 & 2011 & 73.6 & 27 & adult & female & \\
\hline 4 & 28.09. & 2010 & 74 & 26.5 & adult & female & dorsally and ventrally \\
\hline 2 & 06.05. & 2006 & 74 & 27 & adult & male & attached ventrally \\
\hline 6 & 15.08. & 2010 & 74.1 & 28.5 & adult & female & \\
\hline 6 & 10.10 & 2010 & 76.3 & 28.4 & adult & female & \\
\hline
\end{tabular}

body length and $21.2 \mathrm{~mm}$ maximum body width. It is well distinguished by its small size and from the Larger Indian Giant Water Bug L. indicus. The remarkable finding confirms the sympatric occurrence of two species as it was already noticed for New Delhi where both $L$. indicus and L. patruelis were identified by Perez Goodwyn (2006). Furthermore, the presence of L. patruelis in
Sikkim was mentioned by Thirumalai (2007).

The adult male individual bears around 45 ventrally attached pupae of aquatic mites (Hydracarina) on the underside of the thorax between the second and third pairs of legs. The pupae of $1.0 \mathrm{~mm}$ total length contain mites with four visible eye spots and readily developed legs (Image 7). They have a light yellow color with 


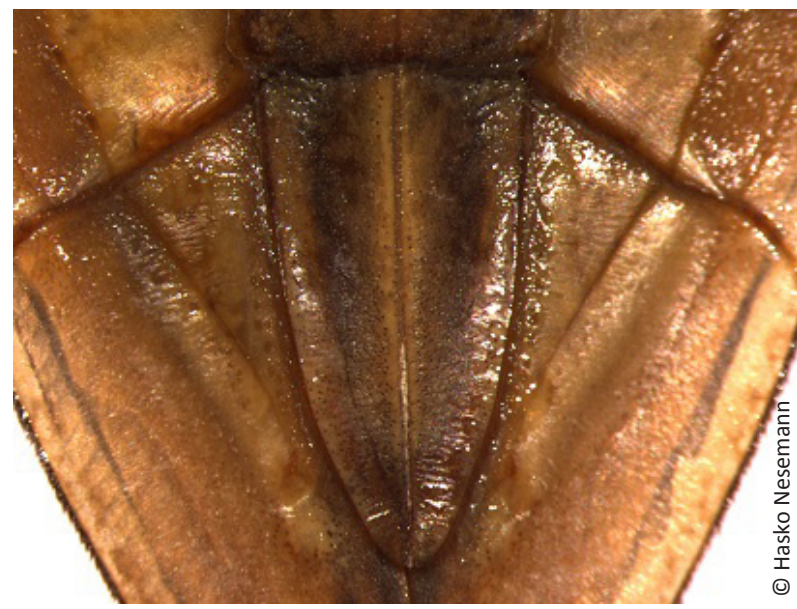

Image 3. Male genital plate of $L$. indicus from locality no. 10.

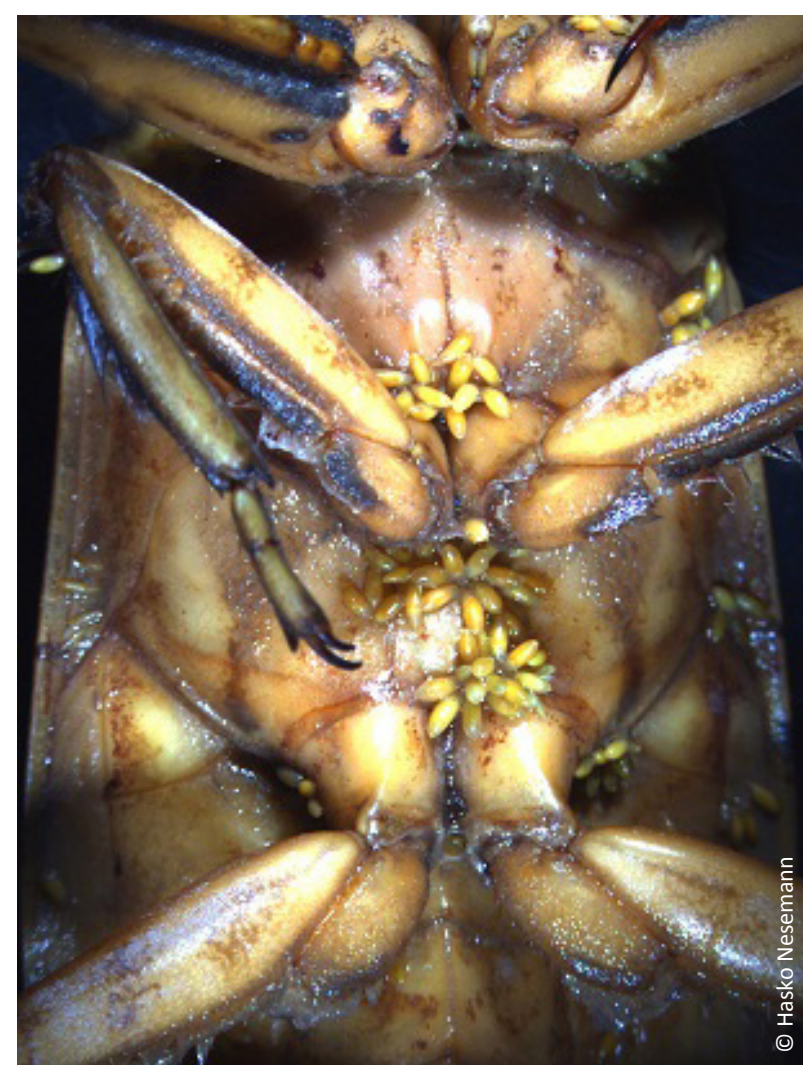

Image 5. Lethocerus indicus, ventral side of adult male from locality no. 9 with attached pupae of juvenile mites (Hydracarina).

white apices. Thus the behavior of the mite's pupal stages resembles the observations which were made for Lethocerus indicus in the lower Gangetic plain.

The habitat is a pollution-free and clear lowland river that originates from the Gangetic plain of northern Bihar. The Budhi Gandak is characterized by a very

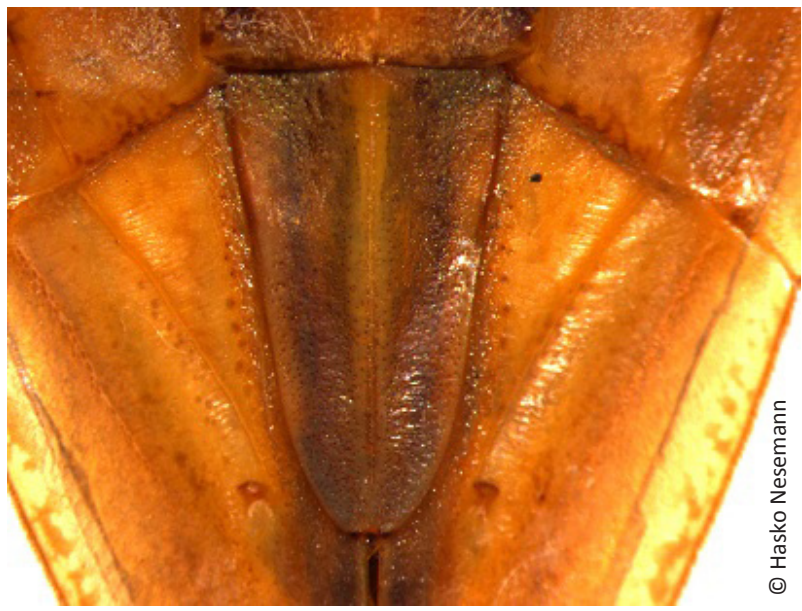

Image 4. Female genital plate of $L$. indicus from locality no. 4.

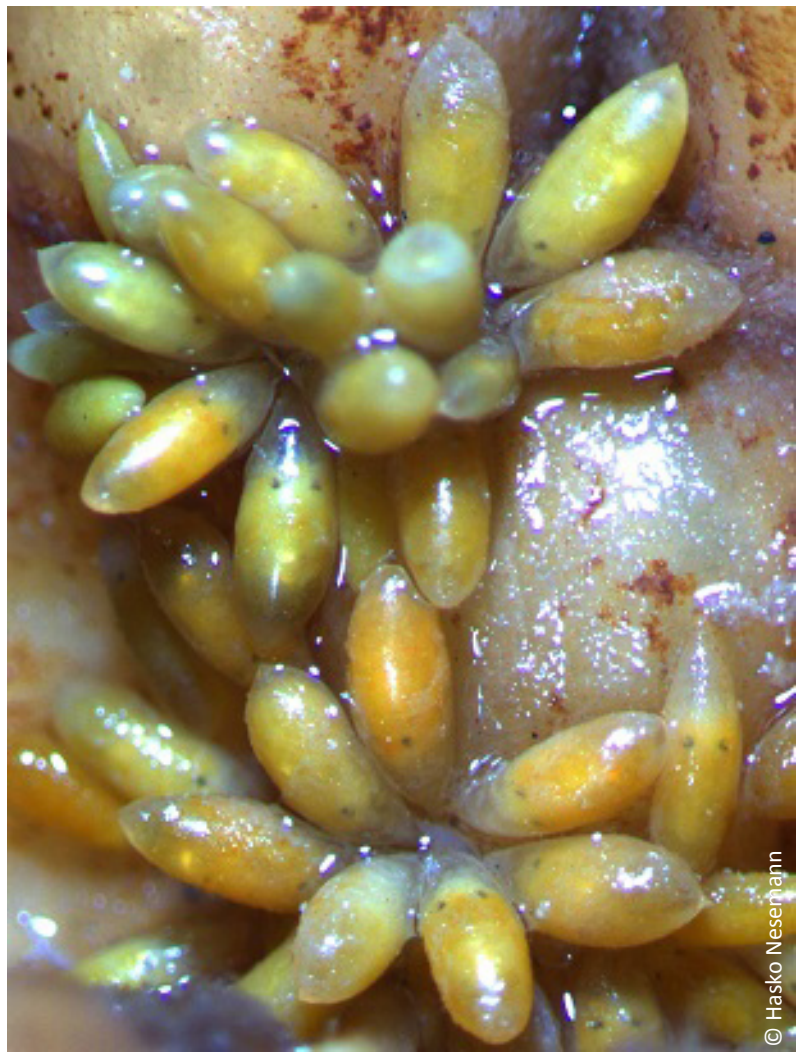

Image 6. Close up of the pupae of juvenile mites (Hydracarina) attached on male Lethocerus indicus from locality no. 9.

dense benthic molluscan fauna (five Bivalvia species, 11 Gastropoda species), the dragon fly nymph Macromia cf. moorei Selys, 1874 and accompanying adult bugs Laccotrephes griseus (Guerin-Meneville, 1844), Laccotrephes ruber (Linnaeus, 1764), Ranatra elongata Fabricius, 1790, Ranatra filiformis Fabricius, 1790. The 


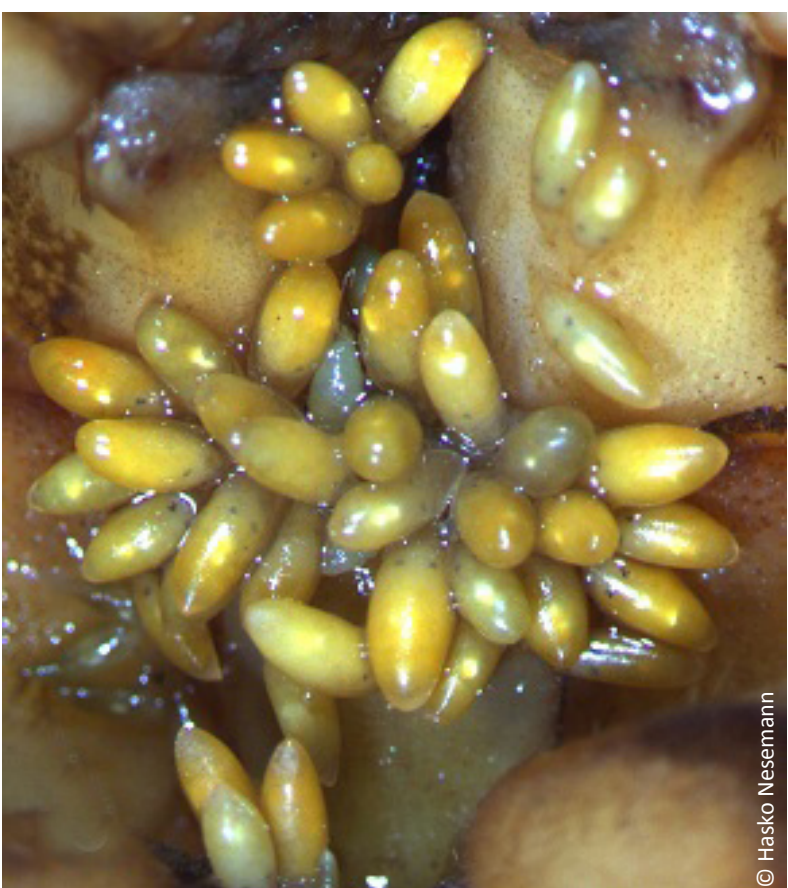

Image 7. Pupae of juvenile mites (Hydracarina) attached on male Lethocerus patruelis from locality no. 17.

total number of macro-invertebrate taxa reaches 25 species at the spot where the adult Lethocerus patruelis has been discovered. Thus water condition and biological community indicate high habitat quality in comparison with Lethocerus indicus habitats which have slightly turbid water and visibly higher eutrophication.

\section{DISCUSSION}

\section{Prey}

The subfamily Lethocerinae is known to be a vertebrate specialist that preys upon fish, amphibians, snakes and juvenile turtles. Lethocerus americanus (Leidy, 1847) is reported to prey also on aquatic Insecta, Cladocera and Gastropoda (Ohba 2011).

\section{Nymphs}

The species identity of nymphs is simply concluded from the adults found in the neighboring localities. It has to be mentioned that neither have their distinguishing characters been sufficiently studied nor have the wingless juvenile development stages of Lethocerus species been considered in the identification keys (Merritt \& Cummins 1996; Goodwyn 2006; Huber et al. 2006). In the present study four instars of Lethocerus indicus were found in the field, also five moltings have been reported for North American species. The smallest nymphs of Lethocerus indicus which were found in the Gandak floodplain from the second half of July onwards already had a body length of 8.5-9 $\mathrm{mm}$.

\section{Habitat selection}

It is noteworthy that the aquatic habitats of the adult Giant Water Bugs of the genus Lethocerus differ from the habitats of their nymphs which suggest a partly divided strategy in their life cycle. The instars of aquatic nymphs do not live in competition or under predatory pressure of fishes since they were found only in temporary water bodies. Thus the strategy to use such habitats for breeding shows the biological importance to protect the nymphs and to provide an easily capable food resource in the form of invertebrates and amphibians such as various sized tadpoles. In contrast, the adult winged stages inhabit permanent water bodies which harbor rich fish diversity.

\section{Protelean 'Parasites'}

These Hydracarina have a complex life-cycle, consisting of a parasitic larva, two inactive pupa-like stages that represent the protonymph and tritonymph, and active predatory deutonymphal and adult stages (Proctor 1998). The attached Hydracarina larvae are parasitic while deutonymphs and adults are predatory. Pupation takes place on the parasitized invertebrate. Our observations show that only adults of Lethocerus species in rivers are colonized by aquatic parasitengone mites. Out of these mostly the second stage (tritonymphs) have been found in the months of May and June (localities no. $2,10,11$ ) whereas a few smaller protonymphs were available in the month of September (locality no. 4). Both species Lethocerus indicus and Lethocerus patruelis bear remarkable similar tritonymphs which may represent the same species of Hydracarina. Although adult mites were not found in the present survey, the nymphs display unique characters that differ from previous observations (Marlos 2010a) as well as other Hydracarina of the study area.

\section{Life cycle of Lethocerus species in the Gangetic plains}

The first instars of aquatic nymphs appear in July and August in shallow temporary water bodies. They grow fast within two months and they molt several times, of which four instars of aquatic nymphs plus the winged adults have been observed. Adult dispersal by flying was seen frequently during the month of October till the first week of November. From winter to the month of June the adult Lethocerus species display an aquatic life style 
inside large water bodies like rivers, oxbow lakes and fishponds. During the aquatic period adult Lethocerus is host to parasitengone aquatic mites (Hydracarina) which spend a part of their life-cycle as parasitic "pupae" (protonymph, tritonymph) attached on adult bugs. Usually they are found in one to three groups attached on the ventral side of males. Tritonymphs of the second development stage of mites are carried from the first week of May to mid-June, smaller protonymphs in September.

\section{REFERENCES}

Bal, A. \& R.C. Basu (2002): Insecta: Hemiptera: Water-Bugs, pp. 7787. In: Ramakrishna (ed.): Fauna of Kawar Lake Wetland (Bihar). Wetland Ecosystem Series 4. Zoological Survey of India, Kolkata, 134pp,

Chen, P.P., N. Nieser \& H. Zettel (2005). The Aquatic and Semi-Aquatic Bugs of Malesia. Fauna of Malesia, Press, HKU, 291-316pp.

Choate, P.M. (2011). Giant Water Bugs, Electric Light Bugs, Lethocerus, Abedus, Belostoma (Insecta: Hemiptera: Belostomatidae). EENY-301 (IN578), pp. 1-6, University of Florida. <http://www.entomology. ifas.ufl.edu/creatures. http://www.edis.ifas.ufl.edu>. Downloaded on 13 January2013.

Cullen, M.J. (1969). The biology of giant water bugs (Hemiptera: Belostomatidae) in Trinidad. Proceedings of the royal entomological Society London (A) 44: 123-127.

Deckert, J. \& U. Göllner-Scheiding (2003). 24. Ordnung Heteroptera, Wanzen, pp. 402-423. In: Dathe, H.H. (ed.): Lehrbuch der Speziellen Zoologie. Band 1: Wirbellose Tiere. 5. Teil: Insecta.

Dudgeon, D. (1999). Tropical Asian Streams: Zoobenthos, Ecology and Conservation. Hong Kong University Press, HKU, 291-316pp.

Easton, E.R. \& Wing-Wah Pun (1997). Observations on some Hemiptera/Heteroptera of Macau, Southeast Asia. Proceedings of the Entomological Society Washington 99 (3): 574-582.

Hawking, J.H., L.M. Smith \& K. Le Busque (eds) (2009). Hydracarina (water mites). In: Identification and Ecology of Australian Freshwater Invertebrates. <http://www.mdfrc.org.au/bugguide>, Version January 2009. Downloaded on 11 February 2013.

Henry, T.J. (2009). Biodiversity of Heteroptera, pp. 223-264. In: Foottit, R. \& P.H. Adler (eds.): Insect Biodiversity, Science and Society. Blackwell Publishing, xxi+632pp.

Hoffman, W.E. (1924). Biological Notes on Lethocerus americanus (Leidy.). Psyche 31(5): 175-183; http://dx.doi. org/10.1155/1924/86146

Hoffman, W.E. (1933a). A preliminary list of the aquatic and semiaquatic Hemiptera of China, Cosen (Korea) and Indo-China. Lingnan Science Journal 12: 243-258.

Hoffman, W.E. (1933b). Additional data on the life history of Lethocerus indicus (Hemiptera: Belostomatidae). Lingnan Science Journal 12 595-601+3pls.

Huber, T., W. Graf \& A. Schmidt-Kloiber (2006). Key to Heteroptera (Bugs). Regional capacity building workshop on Macro-invertebrate Communities to evaluate the ecological status of rivers in the Hindu Kush Himalayan Region. August $20^{\text {th }}$ to September $9^{\text {th }} 2006$, Kathmandu University, Dhulikhel, Nepal, 1-4pp.

Hungerford, H.B. (1925). Notes on the giant water bugs (Lethocerus and Benacus -Belostomatidae Hemiptera). Psyche 32(2): 88-90+1pl; http://dx.doi.org/10.1155/1925/24273

Marlos, D. (2010a). Toe biter with mites? Image submitted by Maria Juliano. <http://www.whatsthatbug.com/2007/05/10/toe-biterwith-mites/.> Assessed on 11.02.2013.
Marlos, D. (2010b). Aquatic mites on water scorpion. Image submitted by Eric Snyder. <http://www.whatsthatbug.com/2009/07/03/ aquatic-mites-on-water-scorpion/.> Assessed on 11.02.2013.

Menke, A. (1960). A review of the genus Lethocerus in the Eastern Hemisphere, with the description of a new species from Australia. Australian Journal of Zoology 8: 258-288.

Merritt, R.W. \& K.W. Cummins (1996). An Introduction to the Aquatic Insects of North America - Third Edition. Kendall/Hunt Publishing Company, lowa, xiii+862pp.

Morse, J.C. (2009). Biodiversity of aquatic insects, pp. 165-184. In: Foottit, R. \& P.H. Adler (eds.). Insect Biodiversity, Science and Society. Blackwell Publishing, xxi+632pp.

Nahar, S.C. (2004). Aquatic insects, pp. 195-213. In: State Fauna Series 11: Fauna of Bihar (Including Jharkhand), Part-1: 195-213, Zoological Survey of India, Kolkata.

Lekprayoon, C., M. Fuangarworn \& E. Mongkolchaichana (2007). The Water Bugs (Hemiptera: Heteroptera) from the Western Thong Pha Phum Research Project Area, Kanchanaburi Province, Thailand. Research Report of Project BRT Western Thong Pha Phum (2550): 38-51. <www.biotec.or.th/.../200-the-water-bugs-hemipteraheteroptera-from... > Downloaded on 20 January 2013.

Nesemann, H., G. Sharma \& M. Sardana (2012). Aquatic macrobenthic Arthropoda diversity of temporary and permanent wetlands in and around Patna with pictorial guide of aquatic bugs (Heteroptera: Nepomorpha). Spectrum Journal of Science and Society for Sustainable Development 2(1-4): 75-84.

Ohba, S. (2011). Field observation of predation on a turtle by a giant water bug. Entomological Science 14(3): 364-365; http://dx.doi. org/10.1111/j.1479-8298.2011.00450.x

Perez-Goodwyn, P.J. (2006). Taxonomic revision of the subfamily Lethocerinae Lauck \& Menke (Heteroptera: Belostomatidae). Stuttgarter Beiträge zur Naturkunde Serie A (Biologie) 695: 1-71.

Perez-Goodwyn, P.J., S. Ohba, \& J.A. Schnack (2006). Chorion morphology of the eggs of Lethocerus delpontei, Kirkaldyia deyrolli, and Horvathinia pelocoroides (Heteroptera: Belostomatidae). Russian Entomological Journal 15(2): 151-156.

Polhemus, J. T. \& D. A. Polhemus (2008). Global diversity of true bugs (Heteroptera; Insecta) in freshwater. Hydrobiologia 595(1): 379391; http://dx.doi.org/10.1007/s10750-007-9033-1

Ponomarenko, A.G. (1985). Fossil insects from the Tithonian, Solnhofener Plattenkalke" in the Museum of Natural History, Vienna. Annalen des Naturhistorischen Museums in Wien 87 A: 135-144.

Popov, Y.A. (1992). Jurassic bugs (Hemiptera: Heteroptera) from the Museum of Natural History in Vienna. Die jurassischen Wanzen (Hemiptera: Heteroptera) des Naturhistorischen Museums in Wien. Annalen des Naturhistorischen Museums in Wien 94 A: 7-14.

Proctor, H. (1998). Parasitengona. Velvet mites, chiggers, water mites. Version 09 August 1998. <http://tolweb.org/ Parasitengona/2581/1998.08.09 in: The Tree of Life Web Project, http://tolweb.org/ >, Downloaded on 11 February 2013.

Sharma, S. (1998). An Inventory of Nepal's Aquatic Insects used as Biological Indicators of Water Pollution. Funded by University Grants Commission, New Beneshwar, Kathmandu, Nepal, 117pp.

Smith, R.L. (1997). Evolution of paternal care in giant water bugs (Heteroptera: Belostomatidae), pp. 116-149. In: Choe, J.C. \& B.J. Crespi (eds.). The Evolution of Social Behavior in Insects and Arachnids. Cambridge University Press.

Smith, R.L. \& E. Larsen (1993). Egg attendance and brooding by males of the Giant Water Bug Lethocerus medius (Guerin) in the field (Heteroptera: Belostomatidae). Journal of Insect Behavior 6: 93-106.

Thirumalai, G. (2007). A Synoptic List of Nepomorha (Hemiptera: Heteroptera) from India. Records of the Zoological Survey of India, Occasional Paper No. 273: 1-84. 